\title{
Germinability and antioxidant metabolism in Passiflora caerulea L. seeds exposed to salt stress
}

\author{
José M. CHAÍN \& Humberto F. CAUSIN \\ Universidad de Buenos Aires. Consejo Nacional de Investigaciones Científicas y Técnicas. Instituto de \\ Biodiversidad y Biología Experimental y Aplicada (IBBEA), Facultad de Ciencias Exactas y Naturales, \\ Departamento de Biodiversidad y Biología Experimental. Ciudad Universitaria, C1428EHA Buenos Aires. \\ Argentina. E-mail H.F. Causin: ssvhfc@gmail.com
}

\begin{abstract}
P. caerulea is the Passiflora species with the widest distribution in Argentina. Despite the need to cultivate it to decrease the extraction impact on its natural populations, the information on how environmental factors affect seed germinability is scarce. In order to evaluate the greminative response and the role of the antioxidant metabolism against saline stress, freshly collected seeds were germinated at $26^{\circ} \mathrm{C}$ in the presence of 0 (control), 30, 60 or $90 \mathrm{mM} \mathrm{NaCl}$. The percentage of germination, the content of soluble and carbonylated proteins, the activity of antioxidant enzymes and the generation of reactive oxygen species both in the pre-germination phase and during germination were evaluated. The removal of the aryl and the micropylar integument after $3 \mathrm{~h}$ imbibition proved to induce a rapid germination and activation of the enzymes catalase, glutathione $\mathrm{S}$-transferase and peroxidases, together with an increase and a decrease in the generation of $\mathrm{O}_{2}{ }^{-}$and $\mathrm{H}_{2} \mathrm{O}_{2}$, respectively, at the root apex. Even though the germination and activity of some of the studied enzymes decreased with the increase in external $\mathrm{NaCl}$ levels, when comparing populations of the control and $90 \mathrm{mM} \mathrm{NaCl}$ treatments having similar germination percentages, a marked induction of peroxidase activity was observed in the latter group. The proportion of carbonylated proteins did not differ among treatments, which suggests that, despite this species cannot be considered as halo-tolerant, the fact that the antioxidant metabolism efficiently contributed to prevent oxidative damage to the proteome may constitute an important mechanism to facilitate its establishment in environments with moderate salinity.
\end{abstract}

Key words: catalase; oxidative stress; Passiflora sp.; peroxidise activity; protein carbonylation; sodium chloride.

Resumen: Germinabilidad y metabolismo antioxidante en semillas de Passiflora caerulea L. expuestas a estrés salino. $P$. caerulea es la especie Passiflora con más amplia distribución en Argentina. Si bien es necesario implementar prácticas de cultivo para disminuir el impacto debido a su extracción indiscriminada, la información sobre cómo los factores ambientales afectan la germinabilidad de sus semillas es escasa. A fin de evaluar la germinabilidad y el rol del metabolismo antioxidante frente al estrés salino, semillas frescas se germinaron en presencia de 0 (control), 30, 60 o $90 \mathrm{mM} \mathrm{NaCl}$. Se evaluó el porcentaje de germinación, el contenido de proteínas solubles y carboniladas, la actividad de enzimas antioxidantes y la generación de especies reactivas de oxígeno tanto en la fase pre-germinativa como durante la germinación. La remoción del arilo y del tegumento micropilar después de $3 \mathrm{~h}$ de imbibición, indujo una rápida germinación y activación de las enzimas catalasa, glutatión S-transferasa y peroxidasas, junto con un aumento y una disminución en la generación de $\mathrm{O}_{2}^{-} \mathrm{y}_{2} \mathrm{O}_{2}$, respectivamente, en el ápice radical. Si bien la germinabilidad y la actividad de algunas de las enzimas estudiadas disminuyeron con el incremento de $\mathrm{NaCl}$, al comparar poblaciones con porcentajes de germinación similares de los tratamientos control y $90 \mathrm{mM} \mathrm{NaCl}$, se observó una marcada inducción de la actividad peroxidasa en estas últimas. La proporción de proteínas carboniladas no difirió entre tratamientos, lo que sugiere que, a pesar de que esta especie no puede considerarse como halo-tolerante, la prevención de daño oxidativo al proteoma puede constituir un mecanismo importante para facilitar su establecimiento en ambientes con moderado estrés salino.

Palabras clave: actividad peroxidasa; catalasa; cloruro de sodio; estrés oxidativo; Passiflora sp.; proteínas carboniladas. 


\section{INTRODUCTION}

Passiflora is a genus with more than 500 species, predominantly tropical and subtropical, most of which have an ornamental, medicinal or edible interest. The attempts to experimentally cultivate some species revealed the existence of serious difficulties in germination and uniformity of seedlings. This may be the result of differences in either seed structure (e.g. hardiness and impermeability of the integuments), in the presence or absence of chemical inhibitors, or in the sensitivity to changes in environmental traits like soil salinity, soil $\mathrm{pH}$ or light intensity (Zucareli et al., 2009; Cárdenas-Hernández et al., 2011; Casierra-Posada et al., 2011; Montaña et al., 2014; dos Santos Moura et al., 2016). Moreover, seeds of many Passiflora species exhibit strong dormancy (Delanoy et al., 2006; Mendiondo \& Amela García, 2009; de Oliveira Júnior et al., 2010; Rego et al., 2014; Neves Marostega et al., 2017).

Amongst the Passiflora species growing in Argentina, $P$. caerulea L. is the one with the widest distribution, finding it from the north to the center of the country in a great variety of habitats (Deginani, 2001). It has many uses, particularly edible or phytotherapeutic (e.g. Martínez Crovetto, 1981; Arenas, 1982; Busilacchi et al., 2008), reason why its natural populations are threatened due to the intense collection without replenishment, and the increasing urbanization of many of the areas where it grows. The implementation of cultivation practices in this species seem to be difficult given that its seeds may show low germination levels, slow germination speed and imbibition periods of months, depending on the pre-germinative treatments and storage conditions used (Mendiondo \& Amela García, 2006; 2009). Although it has been possible to establish that seeds of $P$. caerulea probably present a type of combinational dormancy, the information regarding the requirements to get rapid and homogeneous germination, and the response of seed populations to stress factors is very scanty.

Soil salinization is some of the oldest and most serious environmental problems in the world (Martinez-Beltran \& Manzur, 2005). This phenomenon reduces agricultural outputs by billions of dollars per year around the world, with remediation efforts being difficult and expensive. In addition, salinization may also damage rural infrastructure, water supplies and local economies. Apart from climate and topography, landuse change is one of the most important causes of salinization, a problem that is particularly serious in developing countries like Argentina (Nosetto et al., 2013). In environments with moderate to high salinity, both the decrease in water potential and the accumulation of $\mathrm{Na}^{+}$ and $\mathrm{Cl}^{-}$ions may constitute abiotic stressors that constrain seed germination and seedling establishment of non- halophytic species. It is widely documented that in the face of stressful situations, the production of reactive oxygen species (ROS) increases, with consequent damage to macromolecules and cell integrity (Candan \& Tarhan, 2003; Vaidyanathan et al., 2003; Barcia et al., 2014; Demidchik, 2015). The direct action of ROS on the proteome generates post-translational modifications (PTM) of the oxidative type (Pena et al., 2012), with carbonylation being one of the most frequent (Møller et al., 2007; Madian \& Regnier, 2010). Seeds having proteins as main reserves, like those of $P$. caerulea (Mendiondo \& Amela García, 2009), might be particularly prone to protein oxidation in case of redox imbalances. Carbonylated proteins are mostly targeted for degradation, although they may form degradation-resistant cytosolic aggregates under certain physiological conditions (Maisonneuve et $a l ., 2008)$.

In order to maintain cellular redox homeostasis, plants have a number of both enzymatic and non-enzymatic mechanisms, some of which are stimulated specifically in response to altered ROS levels (Demidchik, 2015). Among them, the activity of antioxidant enzymes like superoxide dismutase (SOD, EC 1.15.1.1), ascorbate peroxidase (APX, EC 1.11.1.11), glutathione peroxidase (GPX, EC 1.11.1.9), glutathione S-transferase (GST, EC 2.5.1.18), guaiacol peroxidase (GPOX, EC 1.11.1.7) and, in particular, the enzyme catalase (CAT, EC 1.11.1.6) have been shown to play an important role in the prevention of oxidative damage in several species and in different types of stress (Willekens et al., 1997; Matsumura et al., 2002; Blokhina et al., 2003; Vandenabeele et al., 2004; Pena et al., 2011; Causin et al., 2015). Studies related to the effect of salt on different stages of development in some Passiflora species indicated that they can be considered as moderately tolerant to salinity stress (e.g. Loureiro Soares et al., 2002; Casierra-Posada et al., 2011; Lourenço Junior et al., 2013; Marler, 2013; Montaña et al., 2014). Nevertheless, only few of them addressed the response to salinity during seed germination and early seedling growth, with little or no knowledge of the relevance of the antioxidant metabolism in this process. 
Although the accumulation of ROS under stress situations is traditionally considered to be responsible for cell damage and changes in seedling growth, it has been reported that its action is necessary for the rupture of dormancy and consequent germination of some seeds (Bailly, 2004). Moreover, there is increasing information supporting the notion that the active production of specific ROS in certain areas of the root contributes to the normal development of the organ (Causin et al., 2012; Kagenishi et al., 2016).

Given that $P$. caerulea renders successfully from either wet forests to xerophytic and anthropically-altered areas, a series of experiments are being undertaken in an attempt to analyze the effect of different abiotic stressors on germination responses and the role of antioxidant defenses during this developmental phase in this species. In the present work, germination performance, protein oxidation, ROS generation and the activity profile of key antioxidant enzymes were studied in freshly collected seeds when exposed to different salinity levels. Our central hypothesis is that a rapid activation and maintenance of the activity of antioxidant enzymes would help preventing oxidative damage, thus facilitating seed germination and seedling establishment under salt or other abiotic stressors.

\section{MATERIALS AND METHODS}

\section{Germination conditions}

P. caerulea seeds were collected at different times during the flowering season from healthy plants that naturally grow on the campus of the Faculty of Sciences in Buenos Aires (34 32 ' 31'" $\left.\mathrm{S}, 58^{\circ} 26^{\prime} 33^{\prime \prime} \mathrm{W}\right)$. The average precipitation amount during the flowering season was $83 \mathrm{~mm}$, with temperatures that ranged between 16.5 and $31.2{ }^{\circ} \mathrm{C}$ (https://www.estadisticaciudad.gob.ar/ eyc/?cat=263). Given that seeds of this species show a very uneven germination, a series of pretreatments were performed to ameliorate their germinability, and the following one proved to meet our requirements: aril removal $+3 \mathrm{~h}$ soaking to soften the integument + removal of the integument at the basal (micropylar) end with pliers $+24 \mathrm{~h}$ soaking under flushing tap water. Seed germination was then performed in Petri dishes with three layers of filter paper embedded in either 0 (control), 30, 60 or $90 \mathrm{mM} \mathrm{NaCl}$, depending on the experiment, which were incubated in the dark at $26^{\circ} \mathrm{C}$. This temperature was chosen because it was representative of the average daily temperature recorded during the period of seed collection. Four replicates containing 35 seeds each were used per condition. Seeds were considered germinated when a radicle of at least $2 \mathrm{~mm}$ length emerged.

\section{Biochemical analyses}

Enzyme activity and protein carbonylation assays were performed either during the pregerminative treatment, as well as at 0,3 and 7 days after sowing (d.a.s.) in the different salinity conditions. Four independent replicates containing 35 seeds each were used per condition and for each sampling date. At a given time, two groups of 14 seeds each (one for the enzymes and the other for the protein carbonylation assays) were randomly taken from each replicate, blotted dry, weighed and kept at $-20^{\circ} \mathrm{C}$ prior to the analyses. For the determination of CAT, APX, GPOX and GST activity, whole seeds (about 0.1 $\mathrm{g}$ fresh weight $(\mathrm{FW})$ were extracted in a mortar, on ice, with $0.6 \mathrm{ml}$ extraction buffer consisting in $50 \mathrm{mM}$ potassium phosphate $\mathrm{pH} 7.6$ plus 1.0 $\mathrm{mM}$ ethylene diamine tetraacetic acid (EDTA), $1.0 \mathrm{mM}$ ascorbic acid, $10.0 \mathrm{mM} \mathrm{MgSO}_{4}, 1.0 \mathrm{mM}$ phenylmethanesulfonyl fluoride (PMSF) and 0.5 $\%$ Triton X-100, in the presence of $2.0 \mathrm{mg}$ polyvinylpolypyrrolidone (PVPP). The extracts were centrifuged at $19,500 \mathrm{~g}$ (two cycles of $25 \mathrm{~min}$ and $12 \mathrm{~min}$, respectively) and immediately used for enzyme assays. APX and GPOX activities were determined as the decrease in optical density of ascorbic acid $\left(\mathrm{A}_{290}\right)$ or increase in optical density of tetraguaiacol ( $\mathrm{A}_{410}$ ), respectively, following the procedures described in Prochazkova et al. (2001). CAT was determined as the decrease in optical density due to hydrogen peroxide $\left(\mathrm{H}_{2} \mathrm{O}_{2}\right.$, $\mathrm{A}_{240}$ ), and expressed as enzymatic units (EU) according to Aebi (1984). GST activity was determined as the absorbance increase at $340 \mathrm{~nm}$ due to the conjugation of the thiol group of GSH (reduced glutathione) to 1-chloro-2,4-dinitrobenzene (CDNB), as described in Habig \& Jakoby (1981).

Carbonyl groups content was assayed in extracts prepared from 14 seeds (i.e. about $0.1 \mathrm{~g}$ FW), homogenized in extraction buffer $(1: 5 \mathrm{FW} / \mathrm{v})$ consisting of $100 \mathrm{mM}$ phosphate buffer ( $\mathrm{pH} 7.4$ ), $120 \mathrm{mM} \mathrm{KCl}$ and $1 \mathrm{mM}$ EDTA, in the presence of $1 \mathrm{mg}$ PVPP. Each homogenate was centrifuged $(10,000 \mathrm{~g}$ for $20 \mathrm{~min})$ with the supernatant fraction used for assays. Protein oxidation was measured colorimetrically in term of total carbonyl groups per mg soluble protein, by reaction with 2,4-dinitrophenylhydrazine (DNPH), according to Levine et al. (1990). 


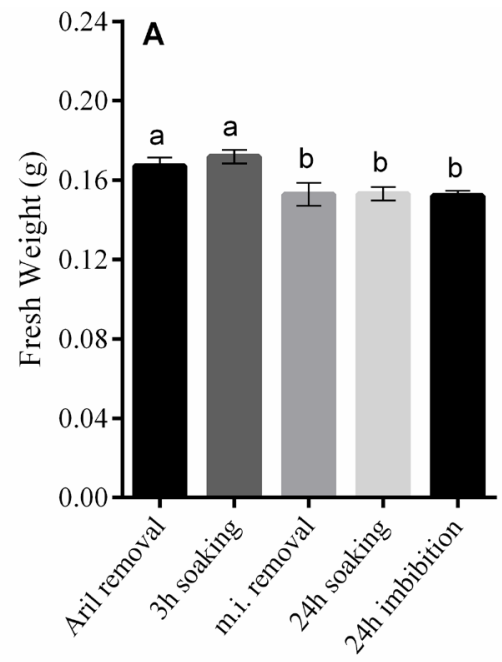

Pre-germinative treatment

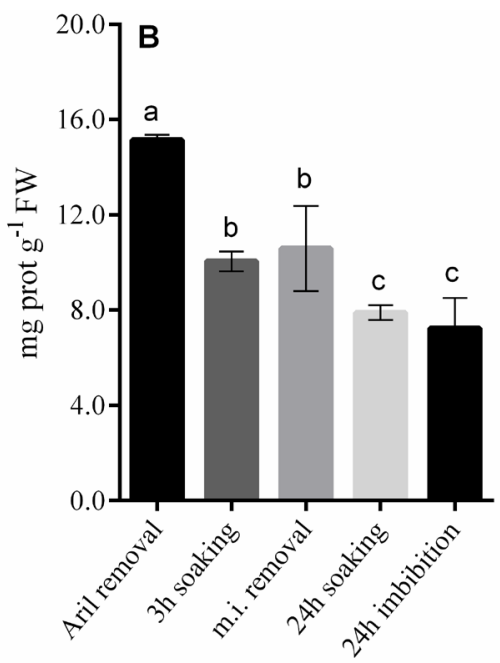

Pre-germinative treatment

Figure 1: Changes in average seed fresh weight (A) and soluble protein concentration (B) in freshly-collected $P$. caerulea seeds during the steps performed in the pre-germinative treatment. Where indicated, $24 \mathrm{~h}$ imbibition stands for placing the seeds on wet filter paper. m.i., micropylar integument. Data are means \pm SD $(n=4)$.

Soluble protein concentration in the extracts was determined according to Bradford (1976), using bovine serum albumin as standard.

A parallel experiment under similar conditions was performed in order to visualize ROS generation. To detect superoxide anion $\left(\mathrm{O}_{2}^{-}\right)$production, seeds devoid of the micropylar integument were infiltrated under vacuum (3 min) and stained for $60 \mathrm{~min}$ with a solution of $0.1 \%(\mathrm{w} / \mathrm{v})$ nitroblue tetrazolium (NBT) in $50 \mathrm{mM}$ potassium phosphate buffer $\mathrm{pH} 7.5$, in the dark (Jabs et al., 1996). To visualize the presence of $\mathrm{H}_{2} \mathrm{O}_{2}$, seeds were infiltrated and stained as above with a solution of $0.1 \%$ 3,3-diaminobenzidine (DAB) in 20 $\mathrm{mM}$ sodium phosphate dibasic, $\mathrm{pH} 4.0$ (modified from Thordal-Christensen et al., 1997). In both cases, after staining, the seeds were rinsed in distilled water and kept in $70 \%$ ethanol at $4{ }^{\circ} \mathrm{C}$ until being analyzed. Seeds were observed under a Zeiss Stemi 2000-C stereomicroscope and photographed with a Sony DSC-S70 camera, adapted to the equipment.

\section{Statistical analyses}

One way ANOVA was used to test whether the physiological traits analyzed showed significant differences after the different steps performed during the pre-germinative treatment. Tuckey HSD post-hoc comparisons were performed to detect homogeneous groups. Two-way ANOVA, with salinity level and d.a.s. as independent vari- ables, was performed to analize data recorded during the germination period at the different salinity levels. When necessary, data were transformed to meet ANOVA assumptions. Tuckey HSD post-hoc comparisons were used to find homogeneous groups when the ANOVA main effects were significant. Unless otherwise stated, data were considered statistically different when $\mathrm{p}<0.05$. All the analyses were performed using the program Graphpad Prism 6.

\section{RESULTS}

Given that the full sequence of steps performed prior to the germination trials where necessary to satisfactorily enhance seed germinability in our conditions, seed samples collected after each of the steps were analyzed in order to evaluate their effect on the physiological traits to be studied thereafter. Despite a slight decrease in the average seed weight was observed after the basal integument was removed, no significant changes in seed FW were recorded after either 3 or $24 \mathrm{~h}$ soaking (Fig. 1A). On the contrary, protein concentration significantly decreased after each soaking period (Fig. 1B). Considering that changes in seed FW were negligible, and that a similar decrement in protein level was observed at $24 \mathrm{~h}$ irrespective of whether the seeds had been soaked under flushing water or directly sown on wet filter paper (Fig. 1B), changes in 
Table 1: Percent of P. caerulea seeds showing positive NBT or DAB staining in the embryo, sampled at different times during the pre-germination treatment, or at $96 \mathrm{~h}$ after sowing in the presence or absence of $90 \mathrm{mM} \mathrm{NaCl}$. Three replicates of 15 - 20 seeds each were analyzed per condition. For each trait, significant differences within treatments are indicated with different letters.

\begin{tabular}{lcc}
\hline Treatment & NBT & DAB \\
\hline & Prior to germination \\
\hline 0 h soaking & $5.0^{\mathrm{a}}$ & $80.1^{\mathrm{a}}$ \\
3 h soaking & $46.7^{\mathrm{b}}$ & $53.3^{\mathrm{b}}$ \\
$24 \mathrm{~h}$ soaking & $86.7^{\mathrm{c}}$ & $26.7^{\mathrm{c}}$ \\
\hline \multicolumn{3}{c}{} \\
\hline $96 \mathrm{~h}(0 \mathrm{mM} \mathrm{NaCl})$ & Germinated \\
$96 \mathrm{~h}(90 \mathrm{mM} \mathrm{NaCl})$ & $73.3^{\mathrm{a}}$ & $13,3^{\mathrm{a}}$ \\
\hline
\end{tabular}

protein content probably reflect an activation of the embryo metabolism and reserve consumption, rather than a dilution due to imbibition, or leakage during water flushing. NBT staining revealed that $\mathrm{O}_{2}$ - generation was almost null in embryos of fresh seeds prior to soaking (Table 1), even though some bluish coloration could be detected in the endosperm region surrounding the radicle in about one third of the seeds analyzed (e.g. Fig. 2A). As the imbibition time increased, a growing percentage of embryos showed blue product formation in their radicles, with the staining being particularly intense at the root apexes of germinated seeds (Table 1, see also Fig. 2C,E and Fig. 3A). Interestingly, the presence of $90 \mathrm{mM} \mathrm{NaCl}$ significantly decreased the percentage of embryos showing positive NBT staining at 4 d.a.s. (Table 1, Fig. 3C: note the lack of NBT staining in a representative seed).

As opposed to NBT, DAB staining was positive in the embryo axis of most of the seeds, and the percentage of stained seeds decreased as soaking and germination time increased, irrespective of the presence or absence of $90 \mathrm{mM} \mathrm{NaCl}$ (Table 1, see also Fig. 2B,D,G and Fig. 3B,D).

The specific activity of CAT and APX increased about three to four folds after 3h soaking, and maintained at that level until seed sowing in the different treatments, at $24 \mathrm{~h}$ (Fig. 4A, B). GST activity also significantly increased, even though the response was more gradual and attained its maximum level after $24 \mathrm{~h}$ imbibition (Fig. 4C). On the contrary, the activity of GPOX was near the limit of detection or null during the
Table 2: Average values of several analyzed traits in $P$. caerulea seeds germinated during 3 days at $0 \mathrm{mM} \mathrm{NaCl}$ (seed lot A) or 7 days at $90 \mathrm{mM} \mathrm{NaCl}$ (seed lot B). Data are means of four independent replicates. Asterisks indicate significant differences between seed lots for the corresponding trait.

\begin{tabular}{lcc}
\hline & \multicolumn{2}{c}{ Seed lot } \\
\cline { 2 - 3 } & $\mathrm{A}$ & $\mathrm{B}$ \\
\cline { 2 - 3 } Germination (\%) & 11.9 & 14.3 \\
Soluble protein (mg g-1 $\left.{ }^{-1} \mathrm{FW}\right)$ & 9.35 & 8.45 \\
Carbonylated proteins & 9.8 & 6.9 \\
$\quad\left(\right.$ nmol mg- ${ }^{-1}$ prot) & & \\
APX specific activity & 0.191 & $0.427^{*}$ \\
GPOX specific activity & 0.026 & $8.584^{*}$ \\
CAT specific activity & 0.779 & 0.713 \\
GST specific activity & 0.019 & 0.022 \\
\hline
\end{tabular}

whole pre-germinative period (data not shown).

The concentration of carbonylated proteins in the soluble fraction was about $25 \mathrm{nmol}$ per $\mathrm{mg}$ protein in fresh seeds without aril, but it decreased from 2.5 to 4 folds after 3 and 24 h soaking, respectively (Fig. 4D).

When seeds were exposed to the salinity treatments, significant reductions of germination rates, as well as a $24 \mathrm{~h}$ increment in the time to initial germination were observed at 60 and $90 \mathrm{mM} \mathrm{NaCl}$ (Fig. 5). These effects were in part related to a decrease in the imbibition and embryo growth rates as suggested by the seed fresh weight profiles obtained during the germination period (Fig. 6A). Maximum germination percent was also significantly reduced in seeds exposed to $90 \mathrm{mM} \mathrm{NaCl}$ when compared to the control (Fig. 5, inset).

The concentration of soluble protein increased to a similar extent in all treatments during the first 3 d.a.s. (Fig. 6B). Then, while soluble protein content continued to increase in the control, 30 and $60 \mathrm{mM} \mathrm{NaCl}$ treatments (though to a lower rate as the $\mathrm{NaCl}$ level increased), no further increment was recorded in the seeds exposed to $90 \mathrm{mM}$ salt.

The activity of peroxidases (APX and GPOX) markedly increased with germination time in all treatments, although the response tended to be higher when seeds were germinated in the presence of $\mathrm{NaCl}$ (Fig. 6C, D). On the contrary, except for the control, CAT activity in the seed population did not significantly increase or even was down-regulated when $\mathrm{NaCl}$ was added to the 


\section{NBT}

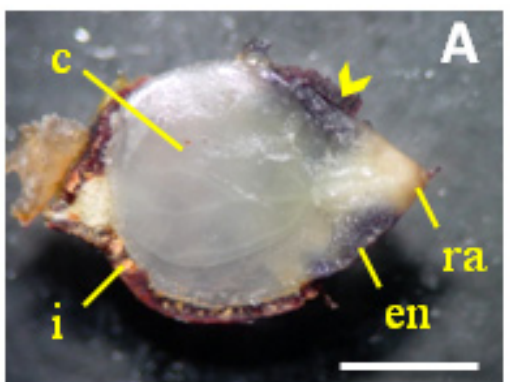

$3 h$

Oh
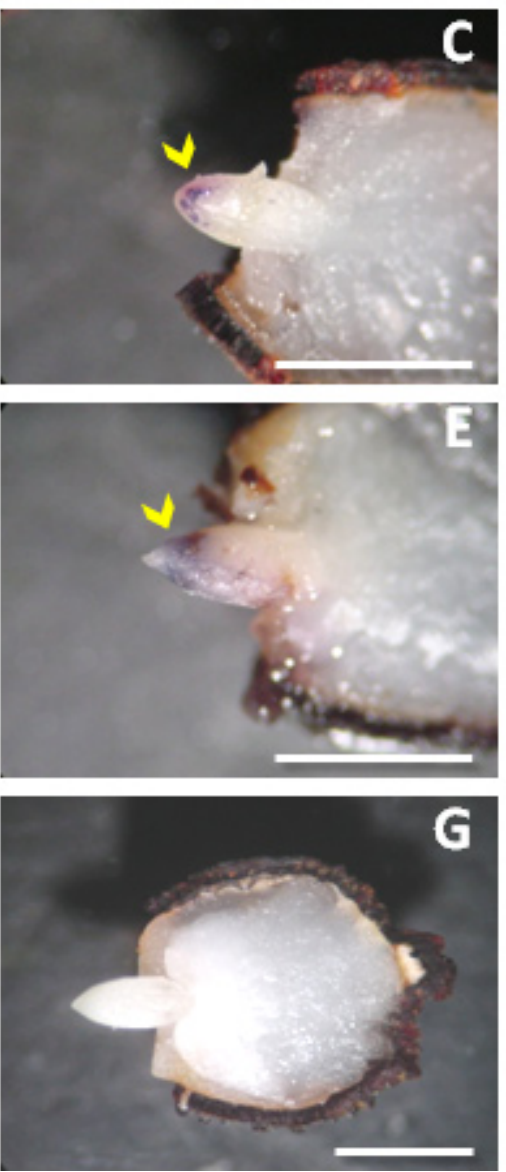

$\mathrm{DAB}$
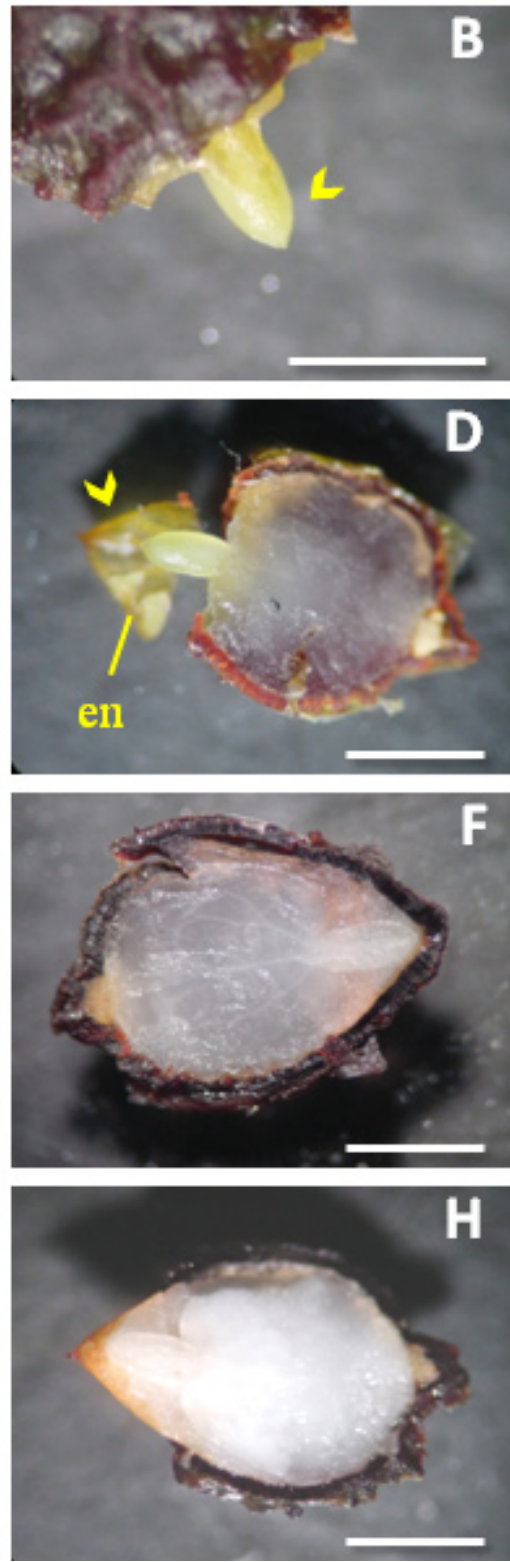

Figure 2: $\mathrm{O}_{2}-$ and $\mathrm{H}_{2} \mathrm{O}_{2}$ generation as revealed by NBT (A, C, E) and DAB (B, D, F) staining (arrowheads), respectively, in freshly collected $P$. caerulea seeds, after 0,3 and $24 \mathrm{~h}$ soaking during the pre-germinative treatment. Seeds without staining are shown as negative controls $(\mathrm{G}, \mathrm{H})$. c, cotyledon; en, endosperm; i, integument; ra, root apex. Bar $=1 \mathrm{~mm}$.

external solution (Fig. 6E). Finally, GST activity also showed a differential pattern: while in the control and $30 \mathrm{mM} \mathrm{NaCl}$ treatments it was found to decrease at 3 d.a.s, but then to significantly increase at 7 d.a.s, the opposite trend was observed in the presence of higher $\mathrm{NaCl}$ levels (Fig. $6 \mathrm{~F}$ ).

Considering that, depending on the sampling date, the proportion of germinated vs. non-germinated seeds significantly differ among some of the treatments compared, it is interesting to discriminate whether the responses observed are triggered by the $\mathrm{NaCl}$ treatment itself, or they are inherent to the differences in the "germinative status" of the seed population sampled. In 
NBT
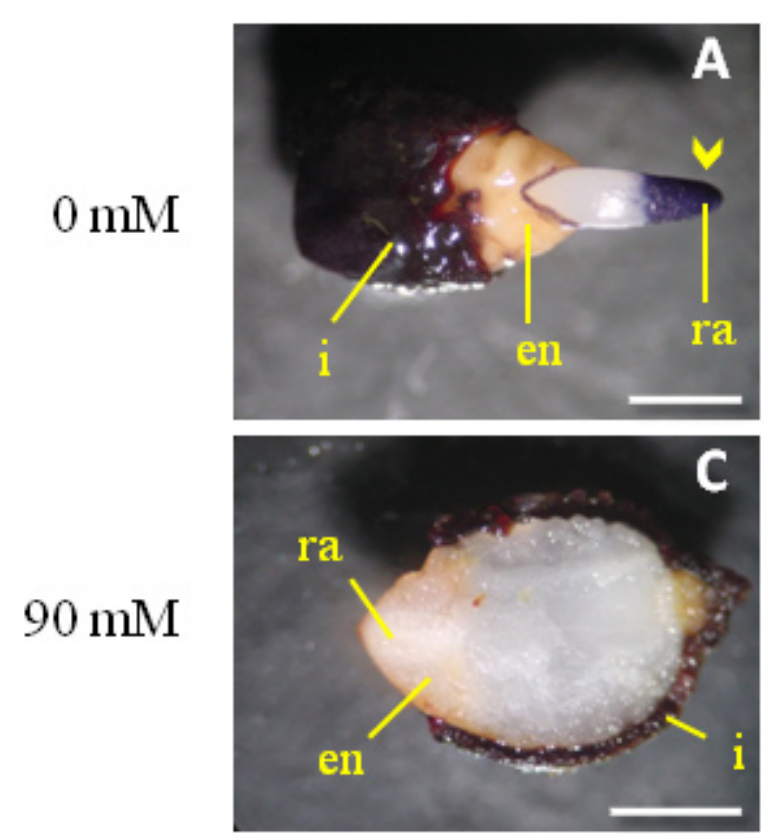

$\mathrm{DAB}$
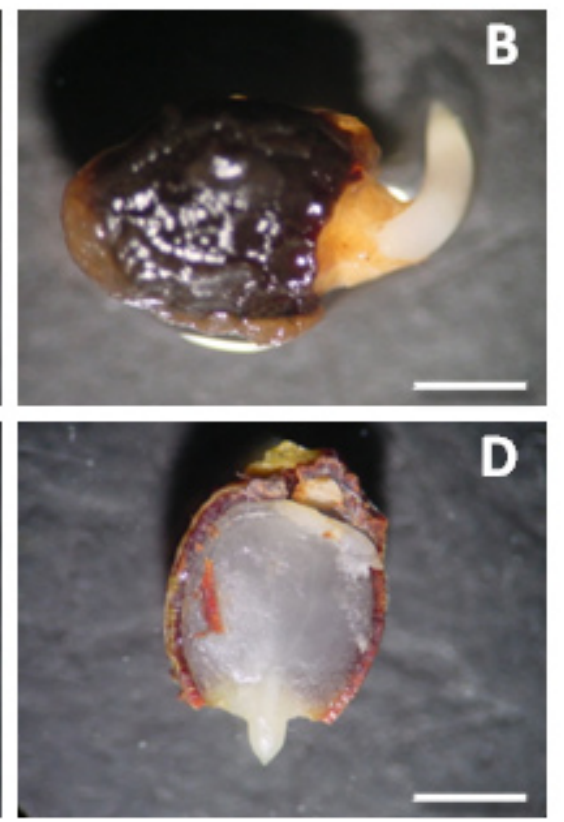

Figure 3: $\mathrm{O}_{2}-$ and $\mathrm{H}_{2} \mathrm{O}_{2}$ generation as revealed by $\mathrm{NBT}(\mathrm{A}, \mathrm{C})$ and DAB (B, D) staining (arrowheads), respectively, in freshly collected $P$. caerulea seeds at $96 \mathrm{~h}$ after sowing in 0 or $90 \mathrm{mM} \mathrm{NaCl}$. Seeds were subjected to a pre-germinative treatment (aril removal $+3 \mathrm{~h}$ soaking to soften the integument + removal of the integument at the micropylar end +24 h soaking) prior to sowing. c, cotyledon; en, endosperm; i, integument; ra, root apex. Bar $=1 \mathrm{~mm}$.

order to differentiate this, we compared data recorded at 7 d.a.s. in seeds exposed to $90 \mathrm{mM} \mathrm{NaCl}$ with data from the control treatment at 3 d.a.s., i.e. when seed populations from these contrasting treatments attained a similar germination percent (Table 2). Among the traits analyzed, only APX and GPOX consistently differed between these seed lots, indicating that the activity of these peroxidases was specifically up-regulated by the presence of $\mathrm{NaCl}$.

Interestingly, the proportion of carbonylated proteins did not show major changes during the germination period in any of the treatments assayed, with the only exception of a slight (but significant) increase in the control treatment at the last sampling date (Fig. 6G).

\section{DISCUSSION AND CONCLUSIONS}

Our data demonstrate that fresh $P$. caerulea seeds show a relatively rapid and even germination rate after aril and basal integument remov$\mathrm{al}$, followed by a $24 \mathrm{~h}$ soaking period. It should be mentioned that aril removal plus soaking alone, acid scarification, or mechanical removal of the apical (cotyledonar) integument prior to soaking were not able to induce a similar response (data not shown), which indicates that the integument structure at the micropylar end imposes an important control for root emergence in this species. In a previous report it was found that, among a series of pre-germinative treatments, aril removal plus $24 \mathrm{~h}$ soaking at room temperature increased total germination percentage and germination rate of $P$. caerulea seeds (Mendiondo \& Amela García, 2006). Nevertheless, both traits showed markedly lower values than those recorded in the present work. It should be noted that, despite chemical and mechanical scarification were also assayed by the mentioned authors without significant modifications of the indicated parameters, they did not try to eliminate the integument at the micropylar end. Removal of the basal integument also proved to significantly increase seed germinability in other Passiflora species (e.g. Delanoy et al., 2006; Alves de Figueiredo Carvalho et al., 2012), an effect that, depending on the species, was enhanced if followed by addition of $\mathrm{GA}_{3}$, indicating that a combination of physical plus physiological dormancy can also be present (Alves de Figueiredo Carvalho et al., 2012).

It has been reported that ROS generation 

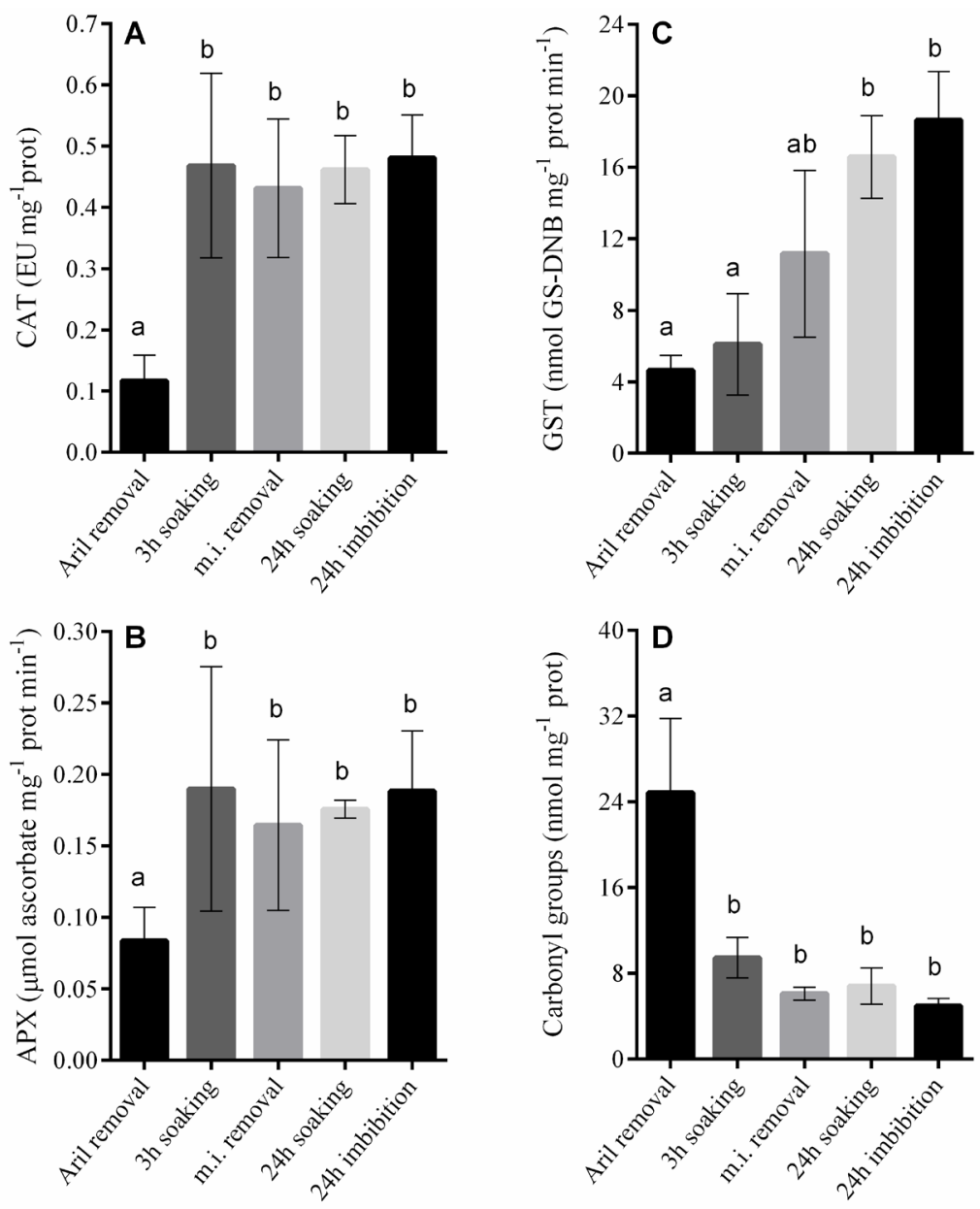

Pre-germinative treatment

Pre-germinative treatment

Figure 4: Changes in the specific activity of CAT (A), APX (B), GST (C) and in the concentration of carbonylated proteins (D), in freshly-collected $P$. caerulea seeds after the pre-germinative treatments. Where indicated, $24 \mathrm{~h}$ imbibition stands for placing the seeds on wet filter paper. m.i., micropylar integument. Data are means $\pm \operatorname{SD}(n=4)$.

during seed imbibition may act as a signaling mechanism to promote germination (e.g. Bailly, 2004). In the present work, evidence of ROS production in the root apex of $P$. caerulea embryos could be detected as soon as after $3 \mathrm{~h}$ soaking in fresh seeds. The fact that embryo metabolism was activated soon after imbibition is also supported by the rapid induction of protein loss. However, while $\mathrm{H}_{2} \mathrm{O}_{2}$ generation as revealed by DAB staining decreased with imbibition time, the number of embryos showing positive NBT staining increased during the pre-germinative period. Moreover, an intense NBT staining persisted in the root apex of germinated seeds, which is in agreement with results reported elsewhere indicating that $\mathrm{O}_{2}-$ generation in the apical zone would be involved in the promotion of normal root growth (Causin et al., 2012; Singh et al., 2014; Kagenishi et al., 2016). Interestingly, NBT staining was markedly down-regulated when germination was performed in the presence of $90 \mathrm{mM} \mathrm{NaCl}$, which suggests that the inability to maintain an adequate $\mathrm{O}_{2}-$ production at the root apex may have contributed to decrease seed germinability in this condition.

The rapid increment of APX, CAT and, to a lesser extent, GST activities during pre-germinative soaking may explain the decrement of the histochemical levels of $\mathrm{H}_{2} \mathrm{O}_{2}$. Moreover, given that ROS generation and oxidation of macromolecules frequently occurs in orthodox seeds during maturation drying, the proper stimulation of the 


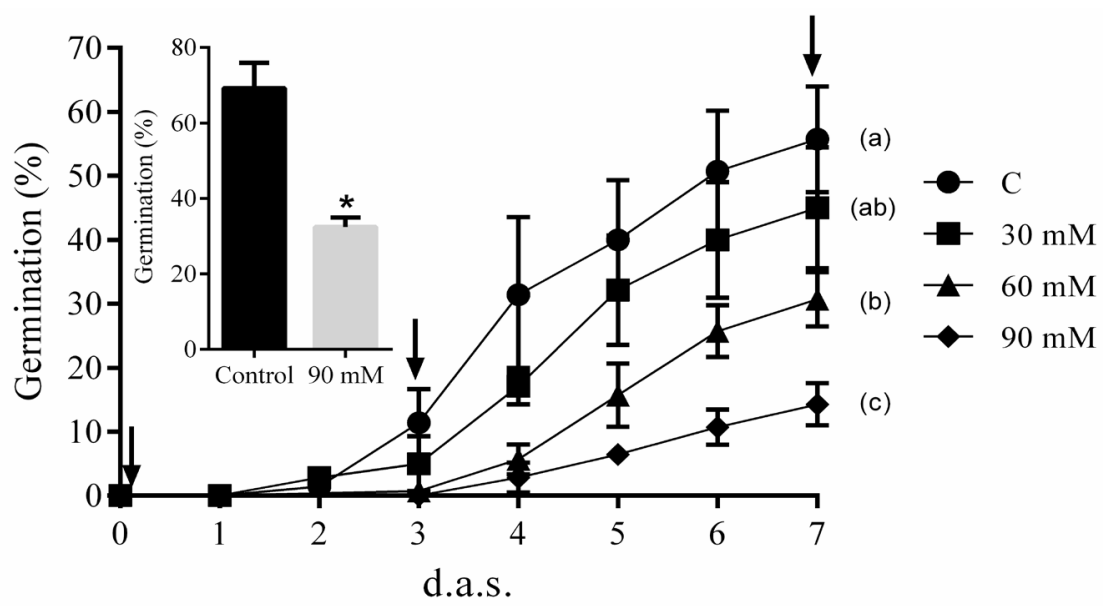

Figure 5: Cumulative germination in freshly collected $P$. caerulea seeds exposed to different NaCl concentrations after the pre-germinative treatment. Sampling times are indicated by arrows. Letters between brackets stand for statistically different groups analyzed at 7 d.a.s. Inset: Maximum germination percent in the control and $90 \mathrm{mM}$ $\mathrm{NaCl}$ treatments (data recorded at 21 d.a.s. ). Data are means $\pm \mathrm{SD}(\mathrm{n}=4)$.

antioxidant machinery during seed imbibition is considered to be of particular importance for the successful repair and/or prevention of further oxidative damage. Hence, it seems feasible to consider that this physiological response also contributed to maintain a low level of protein carbonylation in our experimental conditions.

Given the significant decrement of seed germination rate recorded at moderate salinity levels (i.e. 60 and $90 \mathrm{mM} \mathrm{NaCl}$ ), P. caerulea cannot be considered a salt tolerant species. Nevertheless, the responses observed of the antioxidant enzymes may help understanding why this species is able to establish in ambients with certain environmental constrains. It should be noted that, apart from the marked increment of most of the assayed enzyme activities soon after imbibition, GST and CAT specific activities did not significantly differ between the control and the $90 \mathrm{mM}$ $\mathrm{NaCl}$ treatments when comparing samples with a similar proportion of germinated seeds (Table 2). This indicates that the activity of these enzymes was less sensitive to the presence of $\mathrm{NaCl}$ than seed germinability itself. Among the antioxidant enzymes, there is evidence that the maintenance of an adequate level of CAT activity plays a major role in the prevention of stress symptoms under diverse environmental stimuli (Willekens et al., 1997; Matsumura et al., 2002; Pena et al., 2011; Causin et al., 2015). Nevertheless, the observed strong up-regulation of APX and POX by salt, together with the fact that protein carbonylation was not significantly enhanced in any of the $\mathrm{NaCl}$ concentrations assayed, supports the no- tion that, in this species, the overall performance of the antioxidant metabolism efficiently contributed to prevent oxidative damage in germinating seeds exposed to moderate salinity stress.

\section{ACKNOWLEDGEMENTS}

The authors want to thank Andrea A. Méndez and Marcela Wenzel for their helpful assistance in some of the biochemical analyses performed. We are also grateful to Dr. María T. Amela García for her stimulating ideas.

\section{REFERENCES}

Aebi, H. 1984. Catalase in vitro. Methods in Enzymology 105: $121-126$

Alves de Figueiredo Carvalho, M., R. Paiva, D. Peixoto Vargas, J.M. Padovani Porto, R. Cravo Herrera \& V.C. Stein. 2012. In vitro germination of Passiflora gibertii N. E. Brown with mechanical scarification and gibberellic acid. Semina: Ciências Agrárias, 33: 1027-1032.

Arenas, P. 1982. Recolección y agricultura entre los indígenas Maká del Chaco Boreal. Parodiana 1: 171-243.

Bailly, C. 2004. Active oxygen species and antioxidants in seed biology. Seed Science Research 14, 93-107.

Barcia, R.A., L.B. Pena, M.S. Zawoznik \& S.M. Gallego. 2014. Osmotic adjustment and maintenance of the redox balance in root tissue may be key points to overcome a mild water deficit during the early growth of wheat. Plant Growth Regulation 74: 107117.

Blokhina, O., E. Virolainen \& K.V. Fagerstedt. 2003. Antioxidants, oxidative damage and oxygen depri- 

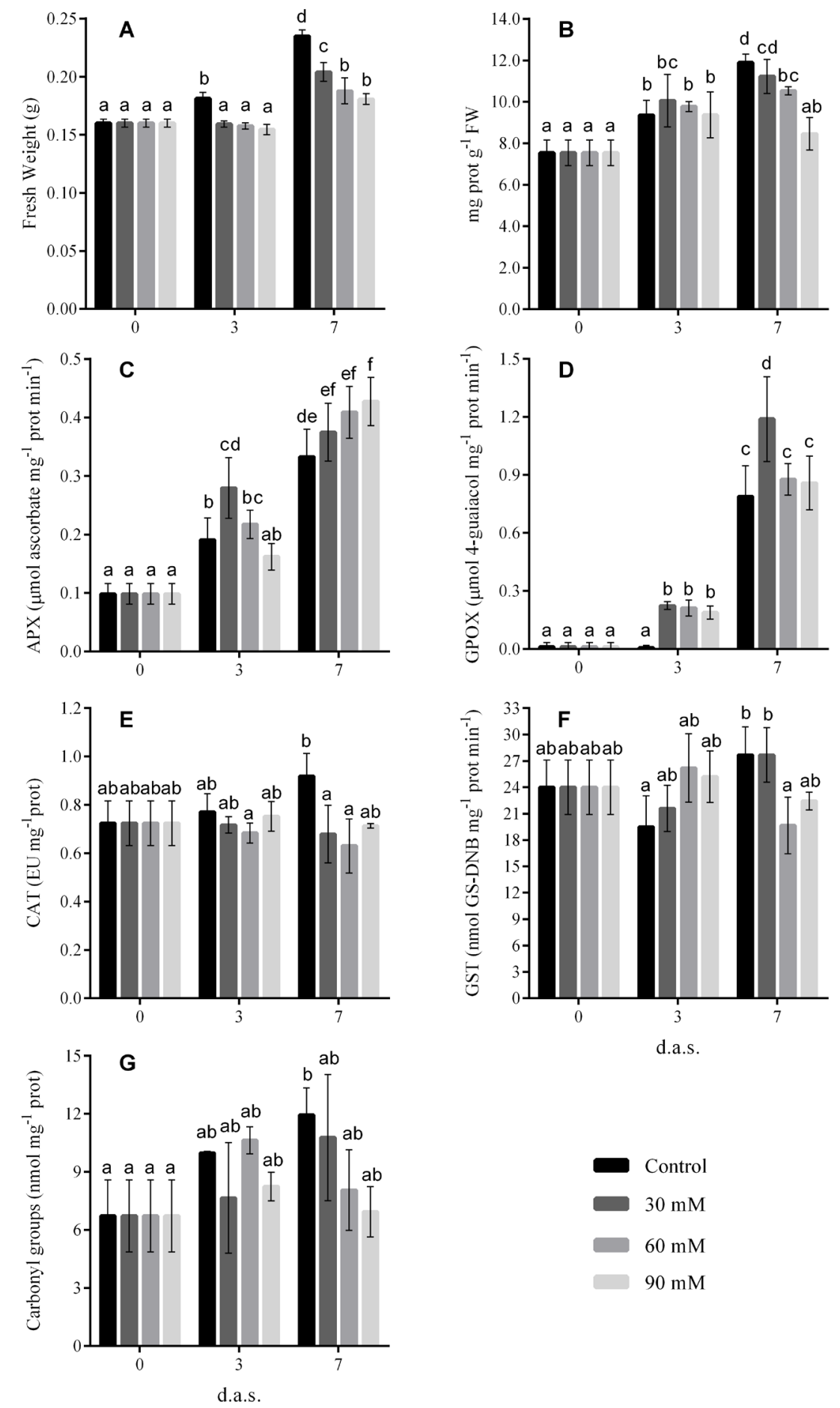

d.a.s.

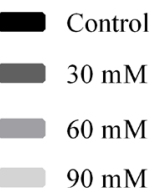

Figure 6: Changes in fresh weight (A), soluble protein concentration (B), specific activity of APX (C), GPOX (D), CAT (E), GST (F) and in the concentration of carbonylated proteins (G), in freshly collected P. caerulea seeds during germination at different $\mathrm{NaCl}$ concentrations, after the pre-germinative treatment. Data are means $\pm \mathrm{SD}(\mathrm{n}=4)$. 
vation stress: A review. Annals of Botany 91: 179194.

Bradford, M.M. 1976. A rapid and sensitive method for the quantitation of microgram quantities of protein using the principle of protein dye binding. Analytical Biochemistry 72: 248-254.

Busilacchi, H., C. Severin, M. Gattuso, A. Aguirre, O. Di Sapio \& S. Gattuso. 2008. Field culture of micropropagated Passiflora caerulea L. histological and chemical studies. Boletín Latinoamericno y del Caribe de Plantas Medicinales y Aromáticas 7: 257 263.

Candan, N. \& L. Tarhan. 2003. The correlation between antioxidant enzyme activities and lipid peroxidation levels in Mentha pulegium organs grown in $\mathrm{Ca}^{2+}, \mathrm{Mg}^{2+}, \mathrm{Cu}^{2+}, \mathrm{Zn}^{2+}$ and $\mathrm{Mn}^{2+}$ stress conditions. Plant Science 163: 769-779.

Cárdenas-Hernández, J., D. Miranda, S. Magnitskiy \& C. Carranza. 2011. Morphological and anatomical analyses of the seed coats of sweet granadilla (Passiflora ligularis Juss.) seeds. Agronomía Colombiana 29: 377-385.

Casierra-Posada, F., J.E. Peña-Olmos \& E. Tejedor. 2011. Growth of banana passion fruit seedlings (Passiflora tripartita var. mollissima (Kunth ) L. H. Bailey) under saline stress. Revista UDCA de Actualidad y Divulgación Científica 14: 31-38.

Causin, H.F., C.F. Marchetti, L.B. Pena, S.M. Gallego \& A.J. Barneix. 2015. Down-regulation of catalase activity contributes to senescence induction in wheat leaves exposed to shading stress. Biologia Plantarum 59: 154-162.

Causin, H.F., G. Roqueiro, E. Petrillo, V. Láinez, L.B. Pena, C.F. Marchetti, S.M. Gallego \& S.B. Maldonado. 2012. The control of root growth by reactive oxygen species in Salix nigra Marsh. seedlings. Plant Science 183: 197-205.

Deginani, N.G. 2001. Las Especies argentinas del género Passiflora. Darwiniana 39, 43-129.

Delanoy, M., P. Van Damme, X. Scheldeman \& J. Beltran. 2006. Germination of Passiflora mollissima (Kunth) L. H. Bailey, Passiflora tricuspis Mast. and Passiflora nov sp. seeds. Scientia Horticulturae (Amsterdam) 110: 198-203.

Demidchik, V. 2015. Mechanisms of oxidative stress in plants: From classical chemistry to cell biology. Environmental and Experimental Botany 109: 212228.

de Oliveira Júnior, M.X., A. Rebouças São José, T.N. Hojo Rebouças, O. Magalhães Morais \& F.W. Novaes Dourado. 2010. Overcoming seeds dormancy of passion fruit (Passiflora cincinnata Mast.). Revista Brasileira de Fruticultura, Jaboticabal 32: 584-590.

dos Santos Moura, R., H.R. Gheyi, M.A. Filho Coelho, O. Nunes de Jesus, F. Vanies da Silva Sá \& L.K. Silva Lima. 2016. Tolerance of passion fruit species under salt stress. International Journal of Current Research 8: 37689-37695.

Jabs, T., R.A. Dietrich \& J.L. Dangl. 1996. Initiation of runaway cell death in an Arabidopsis mutant by extracellular superoxide. Science 273: 1853-1856.
Habig, W.H. \& W.B. Jakoby. 1981. Assays for differentiation of glutathione S-Transferases. Methods in Enzymology 77: 398-405.

Kagenishi, T., K. Yokawa \& F. Baluska. 2016. MES Buffer affects Arabidopsis root apex zonation and root growth by suppressing superoxide generation in root apex. Frontiers in Plant Science 7: 1-8.

Levine, R.L., D. Garland, C.N. Oliver, A. Amici, I. Climent, A.G. Lenz, B.W. Ahn, S. Shaltiel \& E.R. Stadtman. 1990. Determination of carbonyl content in oxidative modified proteins. Methods in Enzymology 106: 464-478.

Loureiro Soares, A.F., H.R. Gheyi, S.B. Assis Viana, C.A. Uyeda \& P. Dantas Fernandes. 2002. Water salinity and initial development of yellow passion fruit. Scientia Agricola 59: 491-497.

Lourenço Junior, J., O. Zambom, M. Santos Rossi \& R.G. Faustini Cuzzuol. 2013. Effects that nutritional and saline gradients have on the growth of Passiflora mucronata Lam. and Canavalia rosea (Sw.) DC. found in the restinga of Brazil. Acta Botanica Brasilica 27: 318-326.

Madian, A.G. \& F.E. Regnier. 2010. Proteomic identification of carbonylated proteins and their oxidation sites. Journal of Proteome Research 9: 3766-3780.

Maisonneuve, E., L. Fraysse, S. Lignon, L. Capron \& S. Dukan. 2008. Carbonylated proteins are detectable only in a degradation-resistant aggregate state in Escherichia coli. Journal of Bacteriology 190: 6609-6614.

Marler, T.E. 2013. Salinity and physiology of Passiflora edulis. Acta Horticulturae 975: 293-298.

Martinez-Beltran, J. \& C.L. Manzur. 2005. Overview of salinity problems in the world and FAO strategies to address the problem. Proceedings of the International Salinity Forum, Riverside, California. pp. 311-313.

Martínez Crovetto, R. 1981. Las plantas utilizadas en medicina popular en el noroeste de Corrientes (Rep. Arg.). Miscelánea 69: 1-139.

Matsumura, T., N. Tabayashi, Y. Kamagata, C. Souma \& H. Saruyama. 2002. Wheat catalase expressed in transgenic rice can improve tolerance against low temperature stress. Physiologia Plantarum 116: 317-327.

Mendiondo, G.M. \& Amela García M.T. 2006. Emergence of Passiflora caerulea seeds simulating possible natural destinies. Fruits 61: 251-258.

Mendiondo, G.M. \& Amela García M.T. 2009. Germination of stored and scarified seeds of Passiflora caerulea L. (Passifloraceae). Plant Biosystems An International Journal Dealing with all Aspects of Plant Biology 143: 369-376.

Møller, I.M., P.E. Jensen \& A. Hansson. 2007. Oxidative modifications to cellular components in plants. Annual Review of Plant Biology 58: 459-481.

Montaña, L.A., G. Fischer, S. Magnitskiy \& G. Zuluaga. 2014. Effect of $\mathrm{NaCl}$ salinity on seed germination and seedling emergence of purple passion fruit (Passiflora edulis Sims). Agronomia Colombiana 32: 188-195. 
Neves Marostega, T., P. Baptista da Luz, A. Reis Tavares, L. Grillo Neves \& S. de Paiva Sobrinho. 2017. Methods of breaking seed dormancy for ornamental passion fruit species. Ornamental Horticulture 23: 72-78.

Nosetto, M.D., A.M. Acosta, D.H. Jayawickreme, S.I. Ballesteros, R.B. Jackson, E.G. Jobbágy. 2013. Land-use and topography shape soil and groundwater salinity in central Argentina. Agricultural Water Management 129: 120- 129

Pena, L.B., C.E. Azpilicueta \& S.M. Gallego. 2011. Sunflower cotyledons cope with copper stress by inducing catalase subunits less sensitive to oxidation. Journal of Trace Elements in Medicine and Biology 25: 125-129.

Pena, L.B., R.A. Barcia, C.E. Azpilicueta, A.A.E. Méndez \& S.M. Gallego. 2012. Oxidative post translational modifications of proteins related to cell cycle are involved in cadmium toxicity in wheat seedlings. Plant Science 196: 1-7.

Prochazkova, D., R.K. Sairam, G.C. Srivastava \& D.V. Singh. 2001. Oxidative stress and antioxidant activity as the basis of senescence in maize leaves. Plant Science 161: 765-771.

Rego, M.M., E.R. Rego, L.P.U. Nattrodt, P.A. Barroso, F.L. Finger \& W.C. Otoni. 2014. Evaluation of different methods to overcome in vitro seed dormancy from yellow passion fruit. African Journal of Biotechnology 13: 3657-3665.

Sheehan, D., G. Meade, V.M. Foley \& C.A. Dowd. 2001. Structure, function and evolution of glutathione transferases: implications for classification of nonmammalian members of an ancient enzyme super- family. Biochemical Journal 360: 1-16.

Singh, K.L., A. Chaudhuri \& R.K. Kar. 2014. Superoxide and its metabolism during germination and axis growth of Vigna radiata (L.) Wilczek seeds. Plant Signaling and Behaviour 9: 1-10.

Thordal-Christensen, H., Z. Zhang, Y. Wei \& D.B. Collinge.1997. Subcellular localization of $\mathrm{H}_{2} \mathrm{O}_{2}$ in plants. $\mathrm{H}_{2} \mathrm{O}_{2}$ accumulation in papillae and hypersensitive response during the barley-powdery mildew interaction. The Plant Journal 11: 1187-1194.

Vaidyanathan, H., P. Sivakumar, R. Chakrabarsty \& G. Thomas. 2003. Scavenging of reactive oxygen species in NaCl-stressed rice (Oryza sativa L.)differential response in salt-tolerant and sensitive varieties. Plant Science 165: 1411-1418.

Vandenabeele, S., S. Vanderauwera, M. Vuylsteke, S. Rombauts, C. Langebartels, H.K. Seidlitz, M. Zabeau, M. Van Montagu, D. Inzé \& F. Van Breusegem. 2004. Catalase deficiency drastically affects gene expression induced by high light in Arabidopsis thaliana. The Plant Journal 39: 4558.

Willekens, H., S. Chamnongpol, M. Davey, M. Schraudner, C. Langebartels, M. Van Montagu, D. Inzé \& W. Van Camp. 1997. Catalase is a sink for $\mathrm{H}_{2} \mathrm{O}_{2}$ and is indispensable for stress defence in C3 plants. The EMBO Journal 16: 4806-4816.

Zucareli, V., G. Ferreira, A.C. Esteves Amaro \& F. Pinheiro de Araújo. 2009. Photoperiod, temperature and plant growth regulators on germination of Passiflora cincinnata Mast. Revista Brasileira das Sementes 31: 106-114.

Doi: 10.22179/REVMACN.20. 563

Recibido: 6-XI-2017

Aceptado: 3- V-2018 